\title{
LITERATURE REVIEW:HUBUNGAN DUKUNGAN SUAMI DENGAN PERILAKU WANITA TERHADAP DETEKSI DINI KANKER SERVIKS METODE INSPEKSI VISUAL ASAM ASETAT (IVA)
}

\section{Fitriani}

Poltekkes Kemenkes Aceh

Email Korespondensi: fitriani@poltekkesaceh.ac.id

Disubmit: 23 Januari 2022 Diterima: 24 Januari 2022 Diterbitkan: 01 Februari 2022

DOI: https://doi.org/10.33024/mnj.v5i2.5892

\section{ABSTRACT: LITERATURE REVIEW: RELATIONSHIP OF HUSBAND SUPPORT WITH WOMEN'S BEHAVIOR TOWARDS EARLY DETECTION OF CERVIC CANCER METHOD OF VISUAL INSPECTION OF ACETIC ACID (IVA)}

Background : Cervical cancer is ranked as the fourth most commonly suffered by women with an estimated 570,000 new cases in 2018 representing 6.6\% of all female cancers in the world and being the fourth highest mortality rate. Early detection of cervical cancer in women aged 30-50 in Indonesia in 2019 showed that 84,1859 IVA positive and 5015 suspected cervical cancer. Early detection program is mainly carried out in cervical and breast cancer which is the highest type of cancer in Indonesia. Screening cervical cancer with the Visual Inspection method of Acetic Acid (IVA) because this method is in accordance with conditions in developing countries including Indonesia, the technique is easy and the sensitivity level is high, fast and accurate enough to find abnormalities at the stage of cell abnormalities or before pre-cancer.

Research objectives: To conduct a review on several literature related to the relationship of Husband Support With Female Behavior towards Early Detection of Cervical Cancer Acetic Acid Visual Inspection Method (IVA)

Research Methods: Using the search method and review of the article "literature review" obtained from 10 articles related to Husband Support With Women's Behavior towards Early Detection of Cervical Cancer Method of Visual Inspection of Acetic Acid (IVA), the article of the last 6 years publication period uses Indonesian and English that fit the criteria and obtained from various article livelihood machines.

Results: Study of 10 articles describing husband support provides a meaningful relationship with IVA behavior and examination measures in Couples of Childbearing Age (PUS), with a range of values a 0,000-0.042 $(<0.05)$ and there are 2 articles of strength correlation variable husband support with wife attitude doing early detection of cervical cancer with IVA test with coefficient correlation $r(0.105)$ and a (0.042) shows a moderate correlation and $p$-value (0.000), with a tightness of $r(0.393)$ indicates a low correlation.

Conclusion: the majority of articles state the existence of a Husband Support Relationship With Women's Behavior towards Early Detection of Cervical Cancer VisualAsam Acetate Inspection Method (IVA).

Keywords: Husband Support, cervical cancer, and Early Detection Behavior IVA methods 


\section{INTISARI: LITERATURE REVIEW:HUBUNGAN DUKUNGAN SUAMI DENGAN PERILAKU WANITA TERHADAP DETEKSI DINI KANKER SERVIKS METODE INSPEKSI VISUAL ASAM ASETAT (IVA)}

Latar Belakang: Kanker serviks menduduki peringkat ke empat paling banyak di derita wanita dengan perkiraan 570.000 kasus baru pada tahun 2018 yang mewakili 6,6\% dari semua kanker wanita didunia serta menjadi angka kematian keempat terbanyak. Hasil pemeriksaan deteksi dini kanker leher rahim pada perempuan usia 30-50 di Indonesia tahun 2019 menunjukkan bahwa ditemukan 84.1859 IVA positif dan 5015 curiga kanker leher rahim.Program deteksi dini utamanya dilakukan pada kanker leher rahim dan payudara yang merupakan jenis kanker tertinggi di Indonesia. Upaya tersebut berupa Screening kanker leher rahim dengan metode Inspeksi Visual Asam Asetat (IVA) karena metode ini sesuai dengan kondisi di negara berkembang termasuk Indonesia, tekniknya mudah dan tingkat sensitivitasnya tinggi, cepat dan cukup akurat untuk menemukan kelainan pada tahap kelainan sel atau sebelum pra-kanker.

Tujuan penelitian: Untuk melakukan review pada beberapa literature terkait dengan hubungan Dukungan Suami Dengan Perilaku Wanita terhadap Deteksi Dini Kanker Serviks Metode Inspeksi Visual Asam Asetat (IVA)

Metode Penelitian: Menggunakan metode penelusuran dan telaah artikel "literature review" yang didapatkan dari 10 artikel yang terkait dengan Dukungan Suami Dengan Perilaku Wanita terhadap Deteksi Dini Kanker Serviks Metode Inspeksi Visual Asam Asetat (IVA),artikel periode publikasi 6 tahun terakhir menggunakan bahasa Indonesia dan bahasa Inggris yang sesuai kriteria dan diperoleh dari berbagai mesin pencaharian artikel.

Hasil : Telaah dari 10 artikel menjelaskan dukungan suami memberikan hubungan yang bermakna dengan perilaku dan tindakan pemeriksaan IVA pada Pasangan Usia Subur (PUS), dengan rentang nilai a $(0.000-0,042)$ dan terdapat 2 artikel kekuatan korelasi variabel dukungan suami dengan sikap istri melakukan deteksi dini kanker leher rahim dengan tes IVA dengan koefisien korelasi $r(0,105)$ dan a (0.042) menunjukkan korelasi sedang serta $p$-value $(0,000)$, dengan keeratan $r(0,393)$ menunjukkan korelasi rendah.

Kesimpulan: Hasil review artikel menjelaskan bahwa Dukungan Suami berkaitan erat Dengan peningkatan upaya wanita terhadap perilaku Deteksi Dini Kanker Serviks Metode Inspeksi Visual Asam Asetat (IVA).

Kata Kunci: Dukungan Suami, kanker serviks dan Perilaku deteksi dini metode IVA 


\section{PENDAHULUAN}

Kanker serviks menduduki peringkat ke empat paling banyak di derita para wanita dengan perkiraan 570.000 kasus baru pada tahun 2018 yang mewakili 6,6\% dari semua kanker wanita didunia serta menjadi angka kematian keempat terbanyak. Sekitar $90 \%$ kematian akibat kanker serviks terjadi dinegara-negara berpenghasilan rendah dan menengah. (World Health Organization 2020)

Di Indonesia, setiap 1 jam seorang perempuan meninggal karena kanker serviks, estimasi kanker serviks 17 per 100.000 perempuan dan kanker ini merupakan kanker kedua terbanyak pada perempuan di Indonesia. (Kesehatan and Indonesia n.d.)

Salah satu penyebab tingginya kejadian kanker serviks di Indonesia adalah rendahnya pemantauan sejak dini. Hasil pemeriksaan deteksi dini kanker leher rahim pada perempuan usia 30-50 di Indonesia tahun 2019 menunjukkan bahwa ditemukan 84.1859 IVA positif dan 5015 dicurigai kanker leher rahim. Persentase cakupan pemeriksaan deteksi dini kanker serviks pada perempuan usia 30-50 tahun menurut provinsi sampai dengan tahun 2019 memuat data bahwa Aceh berada pada posisi ketiga terbawah dengan hanya 2,6\% Wanita Usia Subur (WUS) di Aceh yang telah melakukan pemerikaan deteksi dini kanker serviks, sedangkan Papua pada posisi pertama dengan persentase $0,9 \%$. Hal ini menunjukkan bahwa Wanita Usia Subur (WUS) di Aceh masih rendah minat terhadap pemeriksaan deteksi dini kanker serviks. (Autoridad Nacional del Servicio Civil 2021)

Angka harapan hidup penderita kanker ini masih cukup tinggi jika diketahui dan diobati pada stadium 1 adalah $70-75 \%$, pada stadium 2 adalah $60 \%$, pada stadium 3 tinggal $25 \%$, dan pada stadium 4 penderita sulit diharapkan bertahan. (Autoridad Nacional del Servicio Civil 2021)
Program deteksi dini utamanya dilakukan pada kanker leher rahim dan payudara yang merupakan jenis kanker tertinggi di Indonesia. Upaya tersebut berupa Screening kanker leher rahim dengan metode Inspeksi Visual Asam Asetat (IVA) karena metode ini sesuai dengan kondisi di Negara berkembang termasuk Indonesia (Kesehatan and Indonesia n.d.)

Peran suami dalam membuat keputusan di keluarga yang sangat dominan membuat wanita tidak berdaya untuk memutuskan perawatan dirinya termasuk melakukan skrining kanker serviks. Hasil penelitian Mei Sondang (2019) menyebutkan adanya hubungan yang bermakna antara dukungan suami dengan perilaku WUS dalam melakukan pemeriksaan IVA. (Sondang and Hadi 2019) Hal ini sejalan dengan penelitian yang dilakukan oleh Noviana, dkk (2018) yang menyebutkan ada hubungan signifikan antara dukungan suami dengan perilaku pemeriksaan inspeksi visual asetat (IVA) test dari $\mathrm{p}$-value sebasar 0,021 $(<0,05)$. (Noviana 2019).

\section{METODE}

Metode penelitian ini merupakan penelusuran pustaka, menggunakan aplikasi pencari Google Schoolar, pubmed dan jurnal elektronik lainnya dengan kata kunci bahasa inggris Husband Support for Early Detection of Cervical Cancer (VIA) serta kata kunci bahasa Indonesia hubungan Dukungan Suami Pada Pemeriksaan IVA. Kriteria inklusi penelitian : rentang waktu publikasi 6 tahun terakhir (2014-2020) Artikel full text yang berkaitan dengan deteksi dini kanker serviks, IVA tes pada WUS, Original hasil penelitian,terdiri dari 10 artikel penelitian yaitu 8 artikel penelitian nasional dan 2 artikel penelitian internasional. 
Hasil Temuan literature

\begin{tabular}{|c|c|c|c|c|c|c|c|c|}
\hline No & $\begin{array}{l}\text { Peneliti, } \\
\text { Judul, } \\
\text { Tahun }\end{array}$ & $\begin{array}{c}\text { Tujuan } \\
\text { Penelitian }\end{array}$ & $\begin{array}{c}\text { Rumusan } \\
\text { Masalah }\end{array}$ & Variabel & Design & Metode & Hasil & Kesimpulan \\
\hline 1. & $\begin{array}{l}\text { Noviana } \\
\text { Wulandari, } \\
\text { Tutik Astuti, } \\
\text { dan Siti } \\
\text { Fadhillah } \\
\text { Hubungan } \\
\text { Dukungan } \\
\text { suami } \\
\text { dengan } \\
\text { perilaku } \\
\text { pemeriksaan } \\
\text { Inspeksi } \\
\text { Visual } \\
\text { Asetat (IVA) } \\
\text { Test di } \\
\text { wilayah } \\
\text { kerja } \\
\text { Puskesmas } \\
\text { Cangkringan } \\
\text { Sleman } \\
\text { Yogyakarta. } \\
\text { 2019 }\end{array}$ & $\begin{array}{l}\text { Untuk } \\
\text { mengetah } \\
\text { ui } \\
\text { hubungan } \\
\text { dukungan } \\
\text { suami } \\
\text { dengan } \\
\text { perilaku } \\
\text { pemeriksa } \\
\text { an } \\
\text { Inspeksi } \\
\text { Visual } \\
\text { Asam } \\
\text { Asetat } \\
\text { (IVA) test } \\
\text { di wilayah } \\
\text { kerja } \\
\text { Puskesmas } \\
\text { Cangkring } \\
\text { an Sleman } \\
\text { Yogyakart } \\
\text { a }\end{array}$ & $\begin{array}{l}\text { Adakah } \\
\text { hubungan } \\
\text { antara } \\
\text { dukungan } \\
\text { suami } \\
\text { dengan } \\
\text { perilaku } \\
\text { pemeriksa } \\
\text { an } \\
\text { Inspeksi } \\
\text { Visual } \\
\text { Asam } \\
\text { Asetat } \\
\text { (IVA) test } \\
\text { di wilayah } \\
\text { kerja } \\
\text { Puskesmas } \\
\text { Cangkring } \\
\text { an Sleman } \\
\text { Yogyakart } \\
\text { a? }\end{array}$ & $\begin{array}{l}\text { Variabel } \\
\text { Independ } \\
\text { en : } \\
\text { Dukungan } \\
\text { suami } \\
\text { Variabel } \\
\text { Dependen } \\
\text { : perilaku } \\
\text { pemeriksa } \\
\text { an } \\
\text { Inspeksi } \\
\text { Visual } \\
\text { Asetat } \\
\text { (IVA) test. }\end{array}$ & $\begin{array}{l}\text { Cross } \\
\text { Sectio } \\
\text { nal }\end{array}$ & $\begin{array}{l}\text { Populasi : } \\
\text { Pasangan } \\
\text { Usia Subur } \\
\text { (PUS) yang } \\
\text { pernah } \\
\text { melakukan } \\
\text { pemeriksa } \\
\text { an IVA } \\
\text { test yang } \\
\text { ada di } \\
\text { wilayah } \\
\text { kerja } \\
\text { Puskesmas } \\
\text { Cangkring } \\
\text { an } \\
\text { Sampel : } \\
70 \text { PUS } \\
\text { Teknik } \\
\text { Sampling: } \\
\text { Probabilit } \\
\text { y Samples }\end{array}$ & $\begin{array}{l}\text { Dari } 70 \text { PUS } \\
\text { terdapat } 48 \text { orang } \\
\text { dengan kategori } \\
\text { suami mendukung, } \\
25 \text { diantaranya } \\
\text { terdapat perilaku } \\
\text { pemeriksaan IVA } \\
\text { test pada istri } \\
\text { dengan interval } \\
\text { waktu } \\
\text { pemeriksaanya yaitu } \\
\text { teratur ( } 52,1 \%) \text { dan } \\
23 \text { orang } \\
\text { diantaranya } \\
\text { terdapat perilaku } \\
\text { pemeriksaan IVA } \\
\text { test pada istri } \\
\text { dengan interval } \\
\text { waktu } \\
\text { pemeriksaanya tidak } \\
\text { teratur (47,9\%). } \\
\text { Sedangkan sampel } \\
\text { yang tidak } \\
\text { mendukung } \\
\text { sebanyak } 22 \text { orang, } \\
\text { dengan perilaku } \\
\text { pemeriksaan IVA } \\
\text { test pada istri } \\
\text { teratur sebanyak } 5 \\
\text { orang ( } 22,7 \%) \text { dan } \\
17 \text { orang dengan } \\
\text { pemeriksaan IVA } \\
\text { test pada istri tidak } \\
\text { teratur ( } 77,3 \%) . \\
\text { antuan }\end{array}$ & $\begin{array}{l}\text { Terdapat } \\
\text { hubungan } \\
\text { dukungan } \\
\text { suami } \\
\text { dengan } \\
\text { perilaku } \\
\text { pemeriksaan } \\
\text { IVA test di } \\
\text { Wilayah } \\
\text { Kerja } \\
\text { Puskesmas } \\
\text { Cangkringan } \\
\text { sebesar } \\
\text { 0,021<0,05. } \\
\text { Ini } \\
\text { menunjukka } \\
\text { n bahwa } \\
\text { semakin } \\
\text { suami } \\
\text { mendukung } \\
\text { istri untuk } \\
\text { melakukan } \\
\text { pemeriksaan } \\
\text { IVA test } \\
\text { maka akan } \\
\text { semakin } \\
\text { teratur } \\
\text { perilaku istri } \\
\text { melakukan } \\
\text { pemeriksaan } \\
\text { IVA test. } \\
\text { Banyak } \\
\text { faktor lain } \\
\text { yang } \\
\text { berpengaruh } \\
\text { terhadap } \\
\text { pemeriksaan } \\
\text { IVA test } \\
\text { pada ibu } \\
\text { diantaranya } \\
\text { adalah } \\
\text { pengetahua } \\
\text { n, } \\
\text { pendidikan, } \\
\text { sosial } \\
\text { ekonomi, } \\
\text { dan } \\
\text { kebudayaan }\end{array}$ \\
\hline 2. & $\begin{array}{l}\text { Mei Sondang } \\
\text { dan Ella } \\
\text { Nurlaella } \\
\text { Hadi } \\
\text { Dukungan } \\
\text { Suami } \\
\text { Terhadap } \\
\text { Perilaku } \\
\text { WUS (30-50 } \\
\text { tahun) } \\
\text { dalam } \\
\text { melakukan } \\
\text { pemeriksaan } \\
\text { IVA di } \\
\text { Wilayah } \\
\text { Kerja } \\
\text { Puskesmas }\end{array}$ & $\begin{array}{l}\text { Untuk } \\
\text { mengetah } \\
\text { ui } \\
\text { hubungan } \\
\text { dukungan } \\
\text { suami } \\
\text { dengan } \\
\text { perilaku } \\
\text { WUS (30- } \\
50 \text { tahun) } \\
\text { dalam } \\
\text { melakukan } \\
\text { pemeriksa } \\
\text { an IVA di } \\
\text { wilayah } \\
\text { kerja } \\
\text { Puskesmas } \\
\text { Bondonga } \\
\text { n, Kota }\end{array}$ & $\begin{array}{l}\text { Adakah } \\
\text { hubungan } \\
\text { antara } \\
\text { dukungan } \\
\text { suami } \\
\text { dengan } \\
\text { perilaku } \\
\text { WUS (30- } \\
50 \text { tahun) } \\
\text { dalam } \\
\text { melakukan } \\
\text { pemeriksa } \\
\text { an IVA di } \\
\text { wilayah } \\
\text { kerja } \\
\text { Puskesmas } \\
\text { Bondonga } \\
\text { n, Kota } \\
\text { Bogor }\end{array}$ & $\begin{array}{l}\text { Variabel } \\
\text { Independ } \\
\text { en: } \\
\text { Dukungan } \\
\text { suami } \\
\text { Variabel } \\
\text { Dependen } \\
\text { : perilaku } \\
\text { WUS } \\
\text { dalam } \\
\text { pemeriksa } \\
\text { an } \\
\text { Inspeksi } \\
\text { Visual } \\
\text { Asetat } \\
\text { (IVA) test. }\end{array}$ & $\begin{array}{l}\text { Cross } \\
\text { Sectio } \\
\text { nal }\end{array}$ & $\begin{array}{l}\text { Populasi: } \\
\text { Semua } \\
\text { WUS (30- } \\
50 \text { tahun) } \\
\text { yang } \\
\text { berada di } \\
\text { wilayah } \\
\text { kerja } \\
\text { Puskesmas } \\
\text { Bondonga } \\
\text { n } \\
\text { Sampel: } \\
59 \\
\text { responden } \\
\text { Teknik } \\
\text { Sampling: }\end{array}$ & $\begin{array}{l}\text { Dari } 59 \text { responden, } \\
\text { terdapat } 30 \\
\text { responden yang } \\
\text { mendapat dukungan } \\
\text { suami, diantaranya } \\
\text { terdapat sebanyak } \\
15 \text { orang ( } 50 \%) \\
\text { pernah melakukan } \\
\text { pemeriksaan IVA } \\
\text { dan } 15 \text { orang } \\
\text { lainnya ( } 50 \%) \text { tidak } \\
\text { melakukan } \\
\text { pemeriksaan IVA. } \\
\text { Sementara itu, dari } \\
29 \text { responden yang } \\
\text { tidak mendapat } \\
\text { dukungan suami, } \\
\text { hanya } 1 \text { orang } \\
(3,4 \%) \text { yang pernah }\end{array}$ & $\begin{array}{l}\text { Terdapat } \\
\text { hubungan } \\
\text { yang } \\
\text { bermakna } \\
\text { antara } \\
\text { dukungan } \\
\text { suami } \\
\text { dengan } \\
\text { perilaku } \\
\text { WUS (30-50 } \\
\text { tahun) } \\
\text { dalam } \\
\text { melakukan } \\
\text { pemeriksaan } \\
\text { IVA } \\
\text { diwilayah } \\
\text { kerja } \\
\text { Puskesmas } \\
\text { Bondongan }\end{array}$ \\
\hline
\end{tabular}


TAHUN [MANUJU: MALAHAYATI NURSING JOURNAL, ISSN CETAK: 2655-2728

\begin{tabular}{|c|c|c|c|c|c|c|c|c|}
\hline & $\begin{array}{l}\text { Bondongan. } \\
2019\end{array}$ & $\begin{array}{l}\text { Bogor } \\
\text { Tahun } \\
2018\end{array}$ & $\begin{array}{l}\text { Tahun } \\
2018 ?\end{array}$ & & & $\begin{array}{l}\text { Consecutiv } \\
\text { e sampling }\end{array}$ & $\begin{array}{l}\text { melakukan } \\
\text { pemeriksaan IVA, } \\
\text { selebihnya } 28 \text { orang } \\
(96,6 \%) \text { tidak } \\
\text { melakukan } \\
\text { pemeriksaan IVA. }\end{array}$ & $\begin{array}{l}\text { tahun } 2018 \\
(p=0,001)\end{array}$ \\
\hline 3. & $\begin{array}{l}\text { Inten } \\
\text { Haryati, } \\
\text { Netty, Eka } \\
\text { Handayani } \\
\text { Hubungan } \\
\text { Pengetahua } \\
\text { n dan } \\
\text { Dukungan } \\
\text { Suami } \\
\text { dengan } \\
\text { Keikutsertaa } \\
\text { n dalam } \\
\text { Metode } \\
\text { Pemeriksaan } \\
\text { Inspeksi } \\
\text { Visual Asam } \\
\text { Asetat (IVA) } \\
\text { pada Wanita } \\
\text { Usia Subur } \\
\text { (WUS) } \\
\text { diwilayah } \\
\text { kerja } \\
\text { Puskesmas } \\
\text { Pelaihari } \\
\text { Kabupaten } \\
\text { Tanah Laut. } \\
\text { 2020 }\end{array}$ & $\begin{array}{l}\text { Untuk } \\
\text { mengetah } \\
\text { ui } \\
\text { hubungan } \\
\text { pengetahu } \\
\text { an dan } \\
\text { dukungan } \\
\text { suami } \\
\text { dengan } \\
\text { keikutsert } \\
\text { aan dalam } \\
\text { metode } \\
\text { pemeriksa } \\
\text { an } \\
\text { Inspeksi } \\
\text { Visual } \\
\text { Asam } \\
\text { Asetat } \\
\text { (IVA) } \\
\text { terhadap } \\
\text { WUS } \\
\text { diwilayah } \\
\text { kerja } \\
\text { Puskesmas } \\
\text { Pelaihari } \\
\text { Kabupaten } \\
\text { Tanah } \\
\text { Laut } \\
\text { Tahun } \\
\text { 2020 }\end{array}$ & $\begin{array}{l}\text { Adakah } \\
\text { hubungan } \\
\text { antara } \\
\text { pengetahu } \\
\text { an dan } \\
\text { dukungan } \\
\text { suami } \\
\text { dengan } \\
\text { keikutsert } \\
\text { aan dalam } \\
\text { metode } \\
\text { pemeriksa } \\
\text { an } \\
\text { Inspeksi } \\
\text { Visual } \\
\text { Asam } \\
\text { Asetat } \\
\text { (IVA) } \\
\text { terhadap } \\
\text { WUS } \\
\text { diwilayah } \\
\text { kerja } \\
\text { Puskesmas } \\
\text { Pelaihari } \\
\text { Kabupaten } \\
\text { Tanah } \\
\text { Laut } \\
\text { Tahun } \\
\text { 2020? }\end{array}$ & $\begin{array}{l}\text { Variabel } \\
\text { Independ } \\
\text { en: } \\
\text { Pengetah } \\
\text { uan dan } \\
\text { Dukungan } \\
\text { Suami } \\
\text { Variabel } \\
\text { Dependen } \\
\vdots \\
\text { Keikutsert } \\
\text { aan dalam } \\
\text { metode } \\
\text { pemeriksa } \\
\text { an IVA }\end{array}$ & $\begin{array}{l}\text { Cross } \\
\text { Sectio } \\
\text { nal }\end{array}$ & $\begin{array}{l}\text { Populasi: } \\
\text { semua } \\
\text { WUS yang } \\
\text { berdomisil } \\
\text { i di } \\
\text { Puskesmas } \\
\text { Pelaihari } \\
\text { yaitu } \\
\text { sebanyak } \\
6232 \\
\text { orang } \\
\text { Sampel: } \\
99 \text { orang } \\
\text { Teknik } \\
\text { Sampling: } \\
\text { Purposive } \\
\text { Sampling }\end{array}$ & $\begin{array}{l}\text { Responden dengan } \\
\text { kategori } \\
\text { pengetahuan baik } \\
\text { sebanyak } 42 \\
\text { responden sebagian } \\
\text { besar tidak } \\
\text { melakukan IVA yaitu } \\
22 \text { responden (52\%) } \\
\text { dan yang melakukan } \\
\text { IVA sebanyak 20 } \\
\text { responden (47,6\%). } \\
\text { Pengetahuan } \\
\text { kategori cukup } \\
\text { sebanyak } 37 \\
\text { responden, sebagian } \\
\text { besar tidak } \\
\text { melakukan IVA yaitu } \\
\text { sebanyak } 31 \\
\text { responden ( } 83,8 \%) \\
\text { dan yang melakukan } \\
\text { IVA sebanyak } 6 \\
\text { responden (16,2\%). } \\
\text { Dan pengetahuan } \\
\text { kategori kurang } \\
\text { sebanyak } 20 \\
\text { responden, sebagian } \\
\text { besar tidak pernah } \\
\text { melakukan IVA yaitu } \\
19 \text { responden } \\
\text { (95,0\%) dan yang } \\
\text { melakukan IVA } \\
\text { sejumlah } 1 \\
\text { responden (5,0\%) } \\
\text { Responden dengan } \\
\text { kategori mendukung } \\
\text { sebanyak } 51 \\
\text { responden sebagian } \\
\text { besar tidak } \\
\text { melakukan IVA } \\
\text { sebanyak } 27 \\
\text { responden ( } 52,9 \%) \\
\text { dan yang pernah } \\
\text { melakukan IVA } \\
\text { sebanyak } 24 \\
\text { responden (47,1\%). } \\
\text { Dengan kategori } \\
\text { tidak mendukung } \\
\text { sebanyak } 48 \\
\text { responden sebagian } \\
\text { besar tidak } \\
\text { melakukan IVA yaitu } \\
\text { sebanyak } 45 \\
\text { responden ( } 93,8 \%) \\
\text { dan yang pernah } \\
\text { melakukan IVA } \\
\text { sebanyak } 3 \\
\text { responden (6,4\%). }\end{array}$ & $\begin{array}{l}\text { Terdapat } \\
\text { hubungan } \\
\text { yang } \\
\text { bermakna } \\
\text { antara } \\
\text { pengetahua } \\
n \\
(p=0,000<a \\
0,05) \text { dan } \\
\text { Dukungan } \\
\text { suami } \\
(p=0,000<a \\
0,05) \\
\text { dengan } \\
\text { keikutsertaa } \\
n \text { dalam } \\
\text { metode } \\
\text { pemeriksaan } \\
\text { Inspeksi } \\
\text { Visual Asam } \\
\text { Asetat (IVA) }\end{array}$ \\
\hline 4. & $\begin{array}{l}\text { Desi Aulia } \\
\text { Umami } \\
\text { Hubungan } \\
\text { Dukungan } \\
\text { Suami dan }\end{array}$ & $\begin{array}{l}\text { Untuk } \\
\text { mengetah } \\
\text { ui } \\
\text { hubungan } \\
\text { dukungan } \\
\text { suami dan }\end{array}$ & $\begin{array}{l}\text { Adakah } \\
\text { hubungan } \\
\text { antara } \\
\text { dukungan } \\
\text { suami dan } \\
\text { dukungan }\end{array}$ & $\begin{array}{l}\text { Variabel } \\
\text { Independ } \\
\text { en: } \\
\text { dukungan } \\
\text { suami dan } \\
\text { dukungan }\end{array}$ & $\begin{array}{l}\text { Cross } \\
\text { Sectio } \\
\text { nal }\end{array}$ & $\begin{array}{l}\text { Populasi: } \\
138 \text { WUS } \\
\text { Sampel: } \\
57 \text { WUS }\end{array}$ & $\begin{array}{l}\text { Dari } 57 \text { responden } \\
\text { didapatkan } 29 \text { WUS } \\
\text { dengan dukungan } \\
\text { suami yang buruk } \\
\text { juga sebagian besar } \\
\text { tidak melakukan IVA }\end{array}$ & $\begin{array}{l}\text { Terdapat } \\
\text { hubungan } \\
\text { antara } \\
\text { dukungan } \\
\text { suami } \\
\text { dengan }\end{array}$ \\
\hline
\end{tabular}




\begin{tabular}{|c|c|c|c|c|c|c|c|c|}
\hline & $\begin{array}{l}\text { Dukungan } \\
\text { Petugas } \\
\text { Kesehatan } \\
\text { Terhadap } \\
\text { Perilaku } \\
\text { Pemeriksaan } \\
\text { IVA di } \\
\text { Puskesmas } \\
\text { Padang } \\
\text { Serai. } 2019\end{array}$ & $\begin{array}{l}\text { dukungan } \\
\text { petugas } \\
\text { kesehatan } \\
\text { dengan } \\
\text { pemeriksa } \\
\text { an IVA } \\
\text { pada WUS } \\
\text { di } \\
\text { Puskesmas } \\
\text { Kecamata } \\
\text { n Padang } \\
\text { Serai } \\
\text { Bengkulu } \\
\text { Tahun } \\
\text { 2018. }\end{array}$ & $\begin{array}{l}\text { petugas } \\
\text { kesehatan } \\
\text { dengan } \\
\text { pemeriksa } \\
\text { an IVA } \\
\text { pada WUS } \\
\text { di } \\
\text { Puskesmas } \\
\text { Kecamata } \\
\text { n Padang } \\
\text { Serai } \\
\text { Bengkulu } \\
\text { Tahun } \\
\text { 2018? }\end{array}$ & $\begin{array}{l}\text { petugas } \\
\text { kesehatan } \\
\text { Variabel } \\
\text { Dependen } \\
: \\
\text { Pemeriksa } \\
\text { an IVA } \\
\text { pada WUS }\end{array}$ & & $\begin{array}{l}\text { Teknik } \\
\text { Sampling: } \\
\text { Accidental } \\
\text { sampling }\end{array}$ & $\begin{array}{l}\text { sebanyak } 22 \text { WUS } \\
\text { ( } 38,6 \% \text { ) dan } 7 \text { WUS } \\
\text { yang tetap } \\
\text { melakukan } \\
\text { pemeriksaan IVA. } \\
\text { Lalu didapatkan } 28 \\
\text { WUS dengan } \\
\text { dukungan suami } \\
\text { yang baik, } 16 \text { WUS } \\
(28,1 \%) \text { melakukan } \\
\text { pemeriksaan IVA, } \\
\text { juga } 12 \text { WUS ( } 21 \%) \\
\text { yang sebagian kecil } \\
\text { tidak melakukan IVA }\end{array}$ & $\begin{array}{l}\text { perilaku } \\
\text { pemeriksaan } \\
\text { IVA, dengan } \\
\mathrm{P} . \text { value = } \\
0,016 \\
(\mathrm{P}<0,05) \text { dan } \\
\text { ada } \\
\text { hubungan } \\
\text { antara } \\
\text { dukungan } \\
\text { petugas } \\
\text { kesehatan } \\
\text { dengan } \\
\text { perilaku } \\
\text { pemeriksaan } \\
\text { IVA, dengan } \\
\mathrm{P} . \text { value = } \\
0,032 \\
(\mathrm{P}<0,05)\end{array}$ \\
\hline 5. & $\begin{array}{l}\text { Istiyanah } \\
\text { Ayuningtyas } \\
\text { dan } \\
\text { Ropitasari } \\
\text { Hubungan } \\
\text { Antara } \\
\text { Dukungan } \\
\text { Suami } \\
\text { dengan Istri } \\
\text { Sikap Is } \\
\text { pada Deteksi } \\
\text { Dini Kanker } \\
\text { Leher } \\
\text { RahimMengg } \\
\text { unakan Tes } \\
\text { IVA di } \\
\text { Puskesmas } \\
\text { Jaten II } \\
\text { Kabupaten } \\
\text { Karanganyar } \\
\text {. 2018 }\end{array}$ & $\begin{array}{l}\text { Untuk } \\
\text { mengetah } \\
\text { ui } \\
\text { hubungan } \\
\text { antara } \\
\text { dukungan } \\
\text { suami } \\
\text { dengan } \\
\text { sikap istri } \\
\text { pada } \\
\text { deteksi } \\
\text { dini } \\
\text { kanker } \\
\text { leher } \\
\text { rahim } \\
\text { mengguna } \\
\text { kan tes } \\
\text { IVA di } \\
\text { Puskesmas } \\
\text { Jaten II } \\
\text { Kabupaten } \\
\text { Karangany } \\
\text { ar }\end{array}$ & $\begin{array}{l}\text { Adakah } \\
\text { hubungan } \\
\text { antara } \\
\text { dukungan } \\
\text { suami } \\
\text { dengan } \\
\text { sikap istri } \\
\text { pada } \\
\text { deteksi } \\
\text { dini } \\
\text { kanker } \\
\text { leher } \\
\text { rahim } \\
\text { mengguna } \\
\text { kan tes } \\
\text { IVA di } \\
\text { Puskesmas } \\
\text { Jaten II } \\
\text { Kabupaten } \\
\text { Karangany } \\
\text { ar? }\end{array}$ & $\begin{array}{l}\text { Variabel } \\
\text { Independ } \\
\text { en: } \\
\text { dukungan } \\
\text { suami } \\
\text { Variabel } \\
\text { Dependen } \\
\text { : sikap } \\
\text { istri pada } \\
\text { deteksi } \\
\text { dini } \\
\text { kanker } \\
\text { leher } \\
\text { rahim }\end{array}$ & $\begin{array}{l}\text { Cross } \\
\text { Sectio } \\
\text { nal }\end{array}$ & $\begin{array}{l}\text { Populasi: } \\
\text { PUS } \\
\text { dengan } \\
\text { umur } \geq 30 \\
\text { tahun di } \\
\text { wilayah } \\
\text { Puskesmas } \\
\text { Jaten II } \\
\text { Kabupaten } \\
\text { Karangany } \\
\text { ar } \\
\text { Sampel: } \\
\text { 59 } \\
\text { responden } \\
\text { Teknik } \\
\text { sampling: } \\
\text { Accidental } \\
\text { sampling }\end{array}$ & $\begin{array}{l}\text { Dari } 59 \text { responden } \\
\text { didapatkan } 17 \text { orang } \\
\text { dengan sikap } \\
\text { negatif, } 8 \\
\text { diantaranya } \\
\text { mendapatkan } \\
\text { dukungan suami } \\
\text { kategori kurang } \\
(13,5 \%) \text { dan } 9 \\
\text { diantaranya } \\
\text { mendapatkan } \\
\text { dukungan suami } \\
\text { kategori baik } \\
(15,3 \%) \text {. } \\
\text { Lalu didapatkan } 42 \\
\text { orang dengan sikap } \\
\text { positif, } 15 \\
\text { diantaranya } \\
\text { mendapatkan } \\
\text { dukungan suami } \\
\text { kurang ( } 25,5 \%) \text { dan } \\
27 \text { orang dengan } \\
\text { dukungan suami } \\
\text { kategori baik } \\
\text { (45,7\%). }\end{array}$ & $\begin{array}{l}\text { Terdapat } \\
\text { korelasi } \\
\text { yang } \\
\text { bermakna } \\
\text { antara dua } \\
\text { variabel } \\
\text { yang diuji } \\
\text { dan hasil } \\
\text { koefisien } \\
\text { korelasi } \\
\text { r=0,105 } \\
\text { dengan } \\
\text { tingkat } \\
\text { signifikansi } \\
0.042 \\
\text { menunjukka } \\
\text { n bahwa } \\
\text { kekuatan } \\
\text { korelasi } \\
\text { variabel } \\
\text { dukungan } \\
\text { suami } \\
\text { dengan } \\
\text { sikap istri } \\
\text { melakukan } \\
\text { deteksi dini } \\
\text { kanker leher } \\
\text { rahim } \\
\text { dengan tes } \\
\text { IVA adalah } \\
\text { sedang. }\end{array}$ \\
\hline 6. & $\begin{array}{l}\text { Sri Wahyuni, } \\
\text { Ratna } \\
\text { Puspita dan } \\
\text { Adiyasa } \\
\text { Hubungan } \\
\text { Dukungan } \\
\text { Suami } \\
\text { dengan } \\
\text { Partisipasi } \\
\text { Mengikuti } \\
\text { Pemeriksaan } \\
\text { Inspeksi } \\
\text { Visual Asam } \\
\text { Asetat (IVA) } \\
\text { pada Wanita } \\
\text { Usia Subur } \\
\text { di RW 04 } \\
\text { Kelurahan } \\
\text { Terban } \\
\text { Gondoksuma }\end{array}$ & $\begin{array}{l}\text { Untuk } \\
\text { mengetah } \\
\text { ui } \\
\text { hubungan } \\
\text { dukungan } \\
\text { suami } \\
\text { dengan } \\
\text { partisipasi } \\
\text { mengikuti } \\
\text { pemeriksa } \\
\text { an Visual } \\
\text { Inspeksi } \\
\text { Asam } \\
\text { Asetat } \\
\text { (VIA) pada } \\
\text { wanita } \\
\text { usia subur } \\
\text { di RW 04 } \\
\text { kelurahan } \\
\text { Terban } \\
\text { Gondokus } \\
\end{array}$ & $\begin{array}{l}\text { Adakah } \\
\text { hubungan } \\
\text { antara } \\
\text { dukungan } \\
\text { suami } \\
\text { dengan } \\
\text { partisipasi } \\
\text { mengikuti } \\
\text { pemeriksa } \\
\text { an Visual } \\
\text { Inspeksi } \\
\text { Asam } \\
\text { Asetat } \\
\text { (VIA) pada } \\
\text { wanita } \\
\text { usia subur } \\
\text { di RW 04 } \\
\text { kelurahan } \\
\text { Terban } \\
\text { Gondokus } \\
\text { uman } \\
\end{array}$ & $\begin{array}{l}\text { Variabel } \\
\text { Independ } \\
\text { en: } \\
\text { dukungan } \\
\text { suami } \\
\text { Variabel } \\
\text { Dependen } \\
: \\
\text { Partisipasi } \\
\text { mengikuti } \\
\text { VIA }\end{array}$ & $\begin{array}{l}\text { Cross } \\
\text { Sectio } \\
\text { nal }\end{array}$ & $\begin{array}{l}\text { Populasi: } \\
\text { Seluruh } \\
\text { WUS usia } \\
30-50 \\
\text { tahun di } \\
\text { RW 04 } \\
\text { Kelurahan } \\
\text { Terban } \\
\text { sebanyak } \\
72 \text { orang. } \\
\text { Sampel: } \\
61 \text { orang } \\
\text { Teknik } \\
\text { sampling: } \\
\text { Sampel } \\
\text { proporsi }\end{array}$ & $\begin{array}{l}\text { Dari } 61 \text { orang } \\
\text { terdapat } 39 \\
\text { responden }(63,9 \%) \\
\text { tidak pernah } \\
\text { melakukan } \\
\text { pemeriksaan IVA hal } \\
\text { ini jauh lebih besar } \\
\text { dibandingkan } 22 \\
\text { responden yang } \\
\text { pernah melakukan } \\
\text { IVA ( } 36,1 \% \text { ) terdiri } \\
\text { dari } 7 \text { responden } \\
\text { dengan dukungan } \\
\text { suami kategori } \\
\text { tinggi, } 13 \text { responden } \\
\text { yang mendapatkan } \\
\text { dukungan suami } \\
\text { dengan kategori } \\
\text { sedang dan } 2 \\
\text { responden dengan }\end{array}$ & $\begin{array}{l}\text { Terdapat } \\
\text { hubungan } \\
\text { antara } \\
\text { dukungan } \\
\text { suami } \\
\text { dengan } \\
\text { partisipasi } \\
\text { mengikuti } \\
\text { pemeriksaan } \\
\text { IVA di RW } 04 \\
\text { Kelurahan } \\
\text { Terban } \\
\text { Gondoksuma } \\
\text { n } \\
\text { Yogyakarta } \\
\text { dengan p- } \\
\text { value: } \\
0,000<\text { a:0,0 } \\
04 \text {, dengan } \\
\text { keeratan }\end{array}$ \\
\hline
\end{tabular}




\begin{tabular}{|c|c|c|c|c|c|c|c|c|}
\hline & $\begin{array}{l}\text { n } \\
\text { Yogyakarta. } \\
2018\end{array}$ & $\begin{array}{l}\text { uman } \\
\text { Yogyakart } \\
\text { a }\end{array}$ & $\begin{array}{l}\text { Yogyakart } \\
\text { a? }\end{array}$ & & & & $\begin{array}{l}\text { dukungan suami } \\
\text { kategori rendah. }\end{array}$ & $\begin{array}{l}0,393 \\
\text { (rendah). }\end{array}$ \\
\hline 7 & $\begin{array}{l}\text { M. Rizki } \\
\text { Fathurrohim } \\
\text {, Rodiani, } \\
\text { Rasmi } \\
\text { Zakiah } \\
\text { Oktarlina } \\
\text { dan Nurul } \\
\text { Islamy } \\
\text { Hubungan } \\
\text { Tingkat } \\
\text { Pengetahua } \\
\text { n Wanita } \\
\text { Usia Subur } \\
\text { (WUS) dan } \\
\text { Dukungan } \\
\text { Suami } \\
\text { dengan } \\
\text { Pemeriksaan } \\
\text { Inspeksi } \\
\text { Visual Asam } \\
\text { Asetat (IVA) } \\
\text { sebagai } \\
\text { Metode } \\
\text { Deteksi Lesi } \\
\text { Prakanker } \\
\text { Serviks di } \\
\text { Puskesmas } \\
\text { Kalibalangan } \\
\text { Kabupaten } \\
\text { Lampung } \\
\text { Utara. 2019. }\end{array}$ & $\begin{array}{l}\text { Untuk } \\
\text { mengetah } \\
\text { ui } \\
\text { hubungan } \\
\text { tingkat } \\
\text { pengetahu } \\
\text { an wanita } \\
\text { usia subur } \\
\text { dan } \\
\text { dukungan } \\
\text { suami } \\
\text { terhadap } \\
\text { pemeriksa } \\
\text { an } \\
\text { Inspeksi } \\
\text { Visual } \\
\text { Asam } \\
\text { Asetat } \\
\text { sebagai } \\
\text { pemeriksa } \\
\text { an deteksi } \\
\text { dini lesi } \\
\text { prakanker } \\
\text { serviks }\end{array}$ & $\begin{array}{l}\text { Adakah } \\
\text { hubungan } \\
\text { antara } \\
\text { tingkat } \\
\text { pengetahu } \\
\text { an wanita } \\
\text { usia subur } \\
\text { dan } \\
\text { dukungan } \\
\text { suami } \\
\text { terhadap } \\
\text { pemeriksa } \\
\text { an } \\
\text { inspeksi } \\
\text { visual } \\
\text { asam } \\
\text { asetat } \\
\text { sebagai } \\
\text { pemeriksa } \\
\text { an deteksi } \\
\text { dini lesi } \\
\text { prakanker } \\
\text { serviks? }\end{array}$ & $\begin{array}{l}\text { Variabel } \\
\text { Independ } \\
\text { en: } \\
\text { tingakat } \\
\text { pengetah } \\
\text { uan WUS } \\
\text { dan } \\
\text { dukungan } \\
\text { suami } \\
\text { Variabel } \\
\text { Dependen } \\
\text { : } \\
\text { pemeriksa } \\
\text { an } \\
\text { inspeksi } \\
\text { visual } \\
\text { asam } \\
\text { asetat }\end{array}$ & $\begin{array}{l}\text { Cross } \\
\text { Sectio } \\
\text { nal }\end{array}$ & $\begin{array}{l}\text { Populasi: } \\
\text { Seluruh } \\
\text { wanita } \\
\text { usia subur } \\
\text { yang telah } \\
\text { menikah } \\
\text { Sampel: } \\
196 \\
\text { wanita } \\
\text { Teknik } \\
\text { sampling: } \\
\text { Convenien } \\
\text { ce } \\
\text { sampling }\end{array}$ & $\begin{array}{l}\text { Dari } 196 \text { responden } \\
\text { didapatkan } 144 \\
\text { responden yang } \\
\text { tidak mendapatkan } \\
\text { dukungan suami } \\
(73,5 \%), 130 \text { WUS } \\
\text { diantaranyatidak } \\
\text { pernah melakukan } \\
\text { IVA ( } 90,3 \%) \text { dan } 14 \\
\text { diantaranya pernah } \\
\text { melakukan IVA } \\
\text { ( } 9,7 \%) . \text { Lalu } \\
\text { didapatkan } 52 \text { WUS } \\
\text { dengan adanya } \\
\text { dukungan suami, } \\
\text { sebagian besar } \\
\text { pernah melakukan } \\
\text { IVA sebanyak } 31 \\
\text { WUS (59,6\%) dan } \\
\text { yang tidak pernah } \\
\text { melakukan IVA } \\
\text { sejumlah } 21 \text { WUS } \\
\text { (40,1\%). }\end{array}$ & $\begin{array}{l}\text { Terdapat } \\
\text { hubungan } \\
\text { dukungan } \\
\text { suami } \\
\text { terhadap } \\
\text { pemeriksaan } \\
\text { inspeksi } \\
\text { visual asam } \\
\text { asetat } \\
\text { sebagai } \\
\text { pemeriksaan } \\
\text { deteksi dini } \\
\text { lesi } \\
\text { prakanker } \\
\text { serviks di } \\
\text { Puskesmas } \\
\text { Induk Desa } \\
\text { Kalibalangan } \\
\text { tahun } 2019 \\
\text { dengan } p- \\
\text { value=0.000 } \\
\text {, yang } \\
\text { berarti } \\
\text { p<a=0,05 }\end{array}$ \\
\hline 8. & $\begin{array}{l}\text { Nur Anisah } \\
\text { Rahmawati } \\
\text { dan Linda } \\
\text { Dewanti } \\
\text { Direct } \\
\text { experience } \\
\text { with } \\
\text { Cervical } \\
\text { Cancer } \\
\text { Patient, } \\
\text { Husband } \\
\text { Support, } \\
\text { and Self- } \\
\text { Perception } \\
\text { as } \\
\text { Determinant } \\
\text { Factors of } \\
\text { Women's } \\
\text { Desire to } \\
\text { Take VIA } \\
\text { Screening } \\
\text { Tes. 2018 }\end{array}$ & $\begin{array}{l}\text { Untuk } \\
\text { mempelaj } \\
\text { ari } \\
\text { hubungan } \\
\text { antara } \\
\text { pengalam } \\
\text { an } \\
\text { langsung } \\
\text { dengan } \\
\text { penderita } \\
\text { kanker } \\
\text { serviks, } \\
\text { dukungan } \\
\text { suami, } \\
\text { persepsi } \\
\text { diri } \\
\text { dengan } \\
\text { keinginan } \\
\text { perempua } \\
\text { n } \\
\text { melakukan } \\
\text { skrining } \\
\text { IVA }\end{array}$ & $\begin{array}{l}\text { Adakah } \\
\text { hubungan } \\
\text { antara } \\
\text { pengalam } \\
\text { an } \\
\text { langsung } \\
\text { dengan } \\
\text { penderita } \\
\text { kanker } \\
\text { serviks, } \\
\text { dukungan } \\
\text { suami dan } \\
\text { persepsi } \\
\text { diri } \\
\text { dengan } \\
\text { keinginan } \\
\text { perempua } \\
\text { n } \\
\text { melakukan } \\
\text { skrining } \\
\text { IVA? }\end{array}$ & $\begin{array}{l}\text { Variabel } \\
\text { Independ } \\
\text { en: } \\
\text { pengalam } \\
\text { an } \\
\text { langsung } \\
\text { dengan } \\
\text { penderita } \\
\text { kanker } \\
\text { serviks, } \\
\text { dukungan } \\
\text { suami, } \\
\text { dan } \\
\text { persepsi } \\
\text { diri } \\
\text { Variabel } \\
\text { dependen } \\
\text { : } \\
\text { keinginan } \\
\text { perempua } \\
\text { n } \\
\text { melakuka } \\
\text { n skrining } \\
\text { IVA }\end{array}$ & $\begin{array}{l}\text { Cross } \\
\text { Sectio } \\
\text { nal }\end{array}$ & $\begin{array}{l}\text { Populasi: } \\
4323 \\
\text { wanita } \\
\text { usia 20-55 } \\
\text { tahun } \\
\text { Sampel: } \\
188 \\
\text { responden } \\
\text { Teknik } \\
\text { sampling: } \\
\text { Cluster } \\
\text { sampling }\end{array}$ & $\begin{array}{l}\text { Dukungan suami } \\
\text { (memberi nasehat, } \\
\text { motivasi, } \\
\text { mengingatkan } \\
\text { jadwal tes, dan lain- } \\
\text { lain) untuk } \\
\text { mengikuti tes IVA } \\
\text { adalah rendah }\end{array}$ & $\begin{array}{l}\text { Terdapat } \\
\text { hubungan } \\
\text { antara } \\
\text { persepsi diri } \\
\text { tentang } \\
\text { kanker } \\
\text { serviks dan } \\
\text { dukungan } \\
\text { suami } \\
\text { dengan } \\
\text { keinginan } \\
\text { wanita } \\
\text { untuk } \\
\text { melakukan } \\
\text { skrining IVA } \\
\text { (nilai } \\
\text { p=0,001; } \\
0,002 ; \\
0,007 \text { ) }\end{array}$ \\
\hline 9. & $\begin{array}{l}\text { Puji } \\
\text { Wahyuni, } \\
\text { Christin } \\
\text { Hiyana } \\
\text { Tungga Dewi } \\
\text { dan Ribha } \\
\text { thadhayanti } \\
\text { Determinat } \\
\text { Factors }\end{array}$ & $\begin{array}{l}\text { Untuk } \\
\text { mempelaj } \\
\text { ari faktor } \\
\text { yang } \\
\text { terkait } \\
\text { dengan } \\
\text { partisipasi } \\
\text { tes IVA } \\
\text { pada }\end{array}$ & $\begin{array}{l}\text { ada } \\
\text { hubungan } \\
\text { antara } \\
\text { tingkat } \\
\text { pengetahu } \\
\text { an PUS, } \\
\text { Sikap, } \\
\text { dukungan } \\
\text { suami dan } \\
\text { dukungan }\end{array}$ & $\begin{array}{l}\text { Variabel } \\
\text { Independ } \\
\text { en: } \\
\text { tingkat } \\
\text { Pengetah } \\
\text { uan, } \\
\text { sikap, } \\
\text { dukungan } \\
\text { tenaga } \\
\text { kesehatan }\end{array}$ & $\begin{array}{l}\text { Cross- } \\
\text { sectio } \\
\text { nal }\end{array}$ & $\begin{array}{l}\text { Populasi: } \\
303 \\
\text { wanita } \\
\text { usia subur } \\
\text { Sampel: } \\
75 \\
\text { responden } \\
\text { Teknik } \\
\text { sampling: }\end{array}$ & $\begin{array}{l}\text { Berdasarkan hasil } \\
\text { penelitian ada } \\
\text { hubungan antara } \\
\text { tingkat pengetahuan } \\
\text { dengan partisipasi } \\
\text { tes IVA, } \rho(0,048) \text {. } \\
\text { Tidak ada hubungan } \\
\text { antara sikap dengan } \\
\text { partisipasi tes IVA, } \\
\rho(0,145) \text {. Ada }\end{array}$ & $\begin{array}{l}\text { Ada } \\
\text { hubungan } \\
\text { antara } \\
\text { tingkat } \\
\text { pengetahua } \\
\text { n dengan } \\
\text { partisipasi } \\
\text { tes IVA, } \rho \\
(0,048) \text {. } \\
\text { Tidak ada }\end{array}$ \\
\hline
\end{tabular}




\begin{tabular}{|c|c|c|c|c|c|c|c|c|}
\hline & $\begin{array}{l}\text { Corellated } \\
\text { with IVA } \\
\text { Test } \\
\text { Among } \\
\text { Couple of } \\
\text { Childbearing } \\
\text { Age }\end{array}$ & $\begin{array}{l}\text { pasangan } \\
\text { usia subur }\end{array}$ & $\begin{array}{l}\text { tenaga } \\
\text { kesehatan } \\
\text { dengan } \\
\text { partisipasi } \\
\text { tes IVA }\end{array}$ & $\begin{array}{l}\text { dan } \\
\text { Dukungan } \\
\text { Suami } \\
\text { Variabel } \\
\text { Dependen } \\
: \\
\text { partisipasi } \\
\text { tes IVA }\end{array}$ & & $\begin{array}{l}\text { proportion } \\
\text { al } \\
\text { stratified } \\
\text { random } \\
\text { sampling }\end{array}$ & $\begin{array}{l}\text { hubungan antara } \\
\text { dukungan suami } \\
\text { dengan partisipasi } \\
\text { tes IVA, } \rho(0,000) \text {. } \\
\text { Tidak ada korelasi } \\
\text { antara dukungan } \\
\text { tenaga kesehatan } \\
\text { dengan partisipasi } \\
\text { tes IVA, } \rho(0407) \text {. }\end{array}$ & $\begin{array}{l}\text { hubungan } \\
\text { antara sikap } \\
\text { dengan } \\
\text { partisipasi } \\
\text { tes IVA, } \rho \\
(0,145) \text {. Ada } \\
\text { hubungan } \\
\text { antara } \\
\text { dukungan } \\
\text { suami } \\
\text { dengan } \\
\text { partisipasi } \\
\text { tes IVA, } \rho \\
\text { (0,000). } \\
\text { Tidak ada } \\
\text { korelasi } \\
\text { antara } \\
\text { dukungan } \\
\text { tenaga } \\
\text { kesehatan } \\
\text { dengan } \\
\text { partisipasi } \\
\text { tes IVA, } \rho \\
\text { (0407). }\end{array}$ \\
\hline 10. & $\begin{array}{l}\text { Dewi } \\
\text { Meliasari, } \\
\text { dengan } \\
\text { judul } \\
\text { Pengetahua } \\
\text { n dan } \\
\text { Dukungan } \\
\text { Suami } \\
\text { Berhubunga } \\
\text { n dengan } \\
\text { Tindakan } \\
\text { Pemeriksaan } \\
\text { IVA pada } \\
\text { Pasangan } \\
\text { Usia Subur } \\
\text { (PUS) di } \\
\text { Desa } \\
\text { Sunggal } \\
\text { Kanan. } 2014\end{array}$ & $\begin{array}{l}\text { Untuk } \\
\text { mengetah } \\
\text { ui } \\
\text { hubungan } \\
\text { pengetahu } \\
\text { an dan } \\
\text { dukungan } \\
\text { suami } \\
\text { dengan } \\
\text { tindakan } \\
\text { pemeriksa } \\
\text { an IVA } \\
\text { pada } \\
\text { Pasangan } \\
\text { Usia Subur } \\
\text { (PUS) di } \\
\text { Desa } \\
\text { Sunggal } \\
\text { Kanan } \\
\text { Tahun } \\
\text { 2014 }\end{array}$ & $\begin{array}{l}\text { Adakah } \\
\text { hubungan } \\
\text { pengetahu } \\
\text { an dan } \\
\text { dukungan } \\
\text { suami } \\
\text { dengan } \\
\text { tindakan } \\
\text { pemeriksa } \\
\text { an IVA } \\
\text { pada } \\
\text { Pasangan } \\
\text { Usia Subur } \\
\text { (PUS) di } \\
\text { Desa } \\
\text { Sunggal } \\
\text { Kanan } \\
\text { Tahun } \\
\text { 2014 }\end{array}$ & $\begin{array}{l}\text { Variabel } \\
\text { Independ } \\
\text { en: } \\
\text { Pengetah } \\
\text { uan dan } \\
\text { Dukungan } \\
\text { Suami } \\
\text { Variabel } \\
\text { Dependen } \\
: \\
\text { Tindakan } \\
\text { Pemeriksa } \\
\text { an IVA } \\
\text { pada PUS }\end{array}$ & $\begin{array}{l}\text { Cross } \\
\text { Sectio } \\
\text { nal }\end{array}$ & $\begin{array}{l}\text { Populasi: } \\
\text { Seluruh } \\
\text { PUS di } \\
\text { Desa } \\
\text { Sunggal } \\
\text { Kanan } \\
\text { sebanyak } \\
1545 \\
\text { orang. } \\
\text { Sampel: } \\
94 \\
\text { responden } \\
\text { Teknik } \\
\text { Sampling: } \\
\text { Propotion } \\
\text { al Random } \\
\text { Sampling }\end{array}$ & $\begin{array}{l}\text { Mayoritas suami } \\
\text { yang tidak } \\
\text { mendukung } \\
\text { sebanyak } 64 \text { orang } \\
(68,1 \%) \text { dan } \\
\text { minoritas suami } \\
\text { yangmendukung } \\
\text { sebanyak } 30 \text { orang } \\
(31,9 \%) \text {, dari } 64 \\
\text { responden yang } \\
\text { tidak mendapat } \\
\text { dukungan suami } \\
\text { semuanya tidak } \\
\text { melakukanpemeriks } \\
\text { aan IVA dan dari } 30 \\
\text { responden yang } \\
\text { mendapat dukungan } \\
\text { suami terdapat } 23 \\
\text { orang (76,7\%) yang } \\
\text { melakukan tindakan } \\
\text { pemeriksaan IVA }\end{array}$ & $\begin{array}{l}\text { Adanya } \\
\text { hubungan } \\
\text { yang } \\
\text { signifikan } \\
\text { antara } \\
\text { pengetahua } \\
\text { n dengan } \\
\text { tindakan } \\
\text { pemeriksaan } \\
\text { IVA pada } \\
\text { Pasangan } \\
\text { Usia Subur } \\
\text { (PUS) bahwa } \\
\text { p=0,00<0,00 } \\
5 \text {. } \\
\text { Adanya } \\
\text { hubungan } \\
\text { yang } \\
\text { signifikan } \\
\text { antara } \\
\text { dukungan } \\
\text { suami } \\
\text { dengan } \\
\text { tindakan } \\
\text { pemeriksaan } \\
\text { IVA pada } \\
\text { Pasangan } \\
\text { Usia Subur } \\
\text { (PUS) bahwa } \\
p=0,00\end{array}$ \\
\hline
\end{tabular}




\section{PEMBAHASAN}

Berdasarkan hasil penelusuran pustaka 10 artikel dari 10 jurnal penelitian, Variabel yang dibahas terkait hubungan Dukungan Suami Dengan Perilaku Wanita terhadap Deteksi Dini Kanker Serviks Metode Inspeksi Visual Asam Asetat (IVA), terdapat 10 artikel yang menunjukkan ada hubungan bermakna antara dukungan suami dengan perilaku wanita untuk melakukan deteksi dini kanker serviks metode inspeksi visual asam asetat (IVA).

Pada umumnya suami merupakan orang terdekat dengan WUS dalam berinteraksi dan mengambil keputusan, sehingga hal ini akan sangat mempengaruhi pola pikir WUS dalam bertindak terutama perihal kesehatannya. (Indonesia et al. 2012)

Penelitian Noviana Wulandari, Tutik Astuti, dan Siti Fadhillah (2019) menyatakan bahwa Terdapat hubungan dukungan suami dengan perilaku pemeriksaan IVA test sebesar $\quad 0,021<0,05$. Ini menunjukkan bahwa semakin suami mendukung istri untuk melakukan pemeriksaan IVA test maka akan semakin teratur perilaku istri melakukan pemeriksaan IVA test. Banyak faktor lain yang berpengaruh terhadap pemeriksaan IVA test pada ibu diantaranya adalah pengetahuan, pendidikan, sosial ekonomi, dan kebudayaan. (Noviana 2019)

Demikian pula penelitian oleh Mei Sondang dan Ella Nurlaella Hadi (2018) Terdapat hubungan yang bermakna antara dukungan suami dengan perilaku WUS (30-50 tahun) dalam melakukan pemeriksaan IVA, dengan hasil $p$ value $(0,001)$. Suami memiliki peran sebagai orang terdekat dengan WUS dan suami juga sangat berperan dalam pengambilan keputusan terhadap istri dikarenakan suami memiliki posisi tertinggi dalam keluarga. Hal ini terlihat dari hasil penelitian yang melibatkan 59 WUS usia 30-50 tahun dengan 30 responden mendapat dukungan suami hanya 15 orang yang pernah melakukan pemeriksaan IVA dan 29 responden tidak mendapatkan dukungan suami didapatkan hanya 1 orang yang pernah melakukan pemeriksaan IVA.(Sondang and Hadi 2019).

Hasil penelitian Inten Haryati, Netty, Eka Handayani (2020) menyatakan Ada hubungan yang bermakna antara pengetahuan $(p=0,000<a \quad 0,05)$ dan Dukungan Suami $(p=0,000<a \quad 0,05)$ dengan keikutsertaan dalam metode pemeriksaan inpeksi visual asam asetat (IVA) pada wanita usia subur (WUS). Penelitian ini melibatkan 99 responden, dari 51 WUS yang mendapatkan dukungan terdapat 24 orang pernah melakukan tes IVA dan dari 48 WUS tidak mendapatkan dukungan hanya 3 orang pernah melakukan tes IVA.(Pelaihari et al. 2020)

Penelitian Desi Aulia Utami (2019) bahwa 57 responden tidak mendapatkan dukungan suami dan 16 responden mendapatkan dukungan suami, sehingga dalam penelitian ini disimpulkan bahwa Wanita Usia Subur yang memiliki dukungan suami yang buruk mempunyai peluang 4,190 kali untuk tidak melakukan pemeriksaan IVA. (Umami 2019)

Terdapat 2 artikel yang menyatakan tingkat keeratan antara antara dukungan suami terhadap skrinning IVA dengan koefisien korelasi ( $r$ ) dalam kategori sedang dan rendah yaitu Penelitian Istiyanah Ayuningtiyas dan Ropitasari (2018) The Correlation Between The Support Husband With Attitude Of Wife On Early Detection Cervical Cancer Used IVA Test in 
Public Healthy Center of Jaten II Karanganyar, menyatakan bahwa ada pengaruh yang positif antara dukungan suami dengan sikap istri dalam melakukan tes IVA dengan nilai statistic signifikan $p(0.042)$. Hasil koefisien korelasi $r(0,105)$ menunjukkan kekuatan sedang dengan arah korelasi yang positif bermakna antara dua variabel yang diuji. (Ayuningtiyas, Studi DIV Bidan Pendidik, and Kedokteran Universitas Sebelas Maret Surakarta 2018)

\section{Sementara penelitian Sri} Wahyuni, Ratna Puspita Adiyasa menyimpulkan nilai $p$-value $(0,004)$ Ada hubungan antara dukungan suami dengan partisipasi mengikuti pemeriksaan IVA dengan nilai koefisien kontigensi sebesar 0,393 hal ini menunjukkan bahwa dukungan suami secara simultan memiliki pengaruh yaitu sebesar $39,3 \%$ terhadap partisipasi mengikuti pemeriksaan IVA, Sedangkan sisanya yaitu 60,7 dipengaruhi oleh variabel lain yang tidak diuji dalam penelitian, yang berarti terdapat korelasi yang rendah.(S. Wahyuni and Adiyasa 2018).

Wanita yang mendapatkan dukungan keluarga yang baik akan lebih besar kemungkinan untuk melakukan IVA. Dukungan yang kuat dariorang terdekat termasuk suami cenderung akan membuat responden termotivasi. Peran suami sangat kuat dalam memberikan dukungan bagi ibu untuk melakukan pemeriksaan kesehatan. Selain sebagai penyedia dana, budaya di Indonesia masih menganggap suami juga berperan dalam pengambilan keputusan kemana harus mencari pertolongan dan pengobatan kesehatan. Suami dan keluarga merupakan orang terdekat dengan wanita usia subur untuk bertukar pikiran dan informasi.
Penelitian M. Rizki Fathurrohim, dkk, juga menyatakan Terdapat hubungan pengetahuan wanita usia subur dan dukungan suami terhadap pemeriksaan inspeksi visual asam asetat sebagai pemeriksaan deteksi dini lesi prakanker serviks p-value $(0,000)$ dan OR (13.707), Artinya pengetahuan wanita usia subur dan dukungan suami yang baik akan meningkatkan motivasi wanita 13 kali lipat terhadap pemeriksaan inspeksi visual asam asetat sebagai pemeriksaan deteksi dini lesi prakanker serviks dibandingkan dengan pengetahuan wanita usia subur dan dukungan suami yang buruk. (M. Rizki Fathurrohim, Rodiani, Rasmi Zakiah Oktarlina 2019)

Pengetahuan wanita usia subur tentang pemeriksaan IVA sangat penting, karena pengetahuan memPengaruhi perilaku kunjungan wanita usia subur dalam pemeriksaan IVA. Dengan pemeriksaan IVA yang sederhana, diharapkan cakupan pemeriksaan bisa lebih luas. Apabila penemuan dini lesi prakanker serviks lebih banyak, maka angka kematian akibat kanker serviks dapat ditekan. Berbagai sumber informasi yang saat ini dapat dengan mudah diakses oleh wanita usia subur memungkinkan pengetahuan wanita usia subur tentang kanker serviks dan pemeriksaannya akan semakin baik. Kurangnya pengetahuan dan kesadaran akan pentingnya pemeriksaan menjadi faktor penghambat untuk penapisan kanker serviks. Pengetahuan individu tentang penyakit akan membentuk persepsi individu tentang ancaman penyakit dan kepercayaan terhadap kerentanan penyakit dan akan memotivasi individu untuk melakukan perilaku kesehatan Penelitian Nur Anisah Rahmawati, Linda Dewanti 
menunjukkan bahwa usia, persepsi yang benar, dan dukungan suami berhubungan dengan keinginan perempuan untuk melakukan skrining IVA dengan hasil $p<0.05$, sedangkan pengalaman langsung dengan penderita kanker serviks tidak berhubungan dengan keinginan melakukan skrining. Perempuan dengan persepsi yang benar dan dukungan suami lebih bersedia melakukan skrining IVA. (Rahmawati and Dewanti 2018)

Penelitian Puji Wahyuni, dkk Determinat Factors Corellated with IVA Test Among Couple of Childbearing Age, ada hubungan antara tingkat pengetahuan dengan partisipasi tes IVA, $\rho(0,048)$. Tidak ada hubungan antara sikap dengan partisipasi tes IVA, $\rho(0,145)$. Ada hubungan antara dukungan suami dengan partisipasi tes IVA, $\rho(0,000)$. Tidak ada korelasi antara dukungan tenaga kesehatan dengan partisipasi tes IVA, $\rho$ (0407). (P. Wahyuni, Dewi, and Idhayanti 2019)

Hasil Penelitian Dewi Meliasari diketahui bahwa dari 94 respondem, 30 orang responden yang mendapat dukungan suami yaitu 23 orang $(76,7 \%)$ melakukan tindakan pemeriksaan IVA dan dari 64 responden yang tidak mendapat dukungan suami semuanya tidak melakukan tindakan pemeriksaan IVA. Hasil uji Chi-Square menunjukkan bahwa $p \quad 0,00<0,05$ artinya terdapat hubungan yang signifikan antara dukungan dengan tindakan pemeriksaan IVA. Disimpulkan bahwa Pasangan Usia Subur (PUS) agar dapat menggali pengetahuan dan informasi tentang tindakan pemeriksaan IVA serta mendapat dukungan penuh dari suami untuk melakukan pemeriksaan IVA. (Meliasari 2019).

\section{KESIMPULAN}

Berdasarkan hasil literature review, menjelaskan bahwa Dukungan Suami berkaitan erat Dengan peningkatan upaya wanita terhadap perilaku Deteksi Dini Kanker Serviks Metode Inspeksi Visual Asam Asetat (IVA).

\section{Deklarasi Konflik Kepentingan}

Dalam penelitian ini, penulis menyatakan bahwa tidak ada konflik kepentingan yang substansial baik yang berasal dari institusi atau faktor lain yang terkait dengan penelitian yang telah dilakukan, serta nilai berdasarkan identitas penulis dan nilai publikasi.

\section{DAFTAR PUSTAKA}

Autoridad Nacional del Servicio Civil. (2021). Angewandte Chemie International Edition, 6(11), 951-952. 済無No Title No Title No Title.

Ayuningtiyas, Istiyanah, Program Studi DIV Bidan Pendidik, and Fakultas Kedokteran Universitas Sebelas Maret Surakarta. (2018). "The Correlation Between The Support Husband With Attitude Of Wife On Early Detection Cervical Cancer Used IVA Test in Public Healthy Center Of Jaten II Karanganyar." PLACENTUM Jurnal Ilmiah Kesehatan dan Aplikasinya 6(2): 2018.

Indonesia, Universitas et al. (2012). "Faktor-Faktor Yang Berhubungan Dengan Kabupaten Kebumen Tahun 2012 Faktor-Faktor Yang Berhubungan Dengan Kabupaten Kebumen Tahun 2012."

Kesehatan, Kementerian, and Republik Indonesia. "No Title." M. Rizki Fathurrohim, Rodiani, Rasmi 
Zakiah Oktarlina, Nurul Islamy. (2019). "Hubungan Tingkat Pengetahuan Wanita Usia Subur (WUS) Dan Dukungan Suami Dengan Pemeriksaan Inspeksi Visual Asam Asetat (IVA) Sebagai Metode Deteksi Lesi Prakanker Serviks Di Puskesmas Kalibalangan Kabupaten Lampung Utara Tahun 2019." Medula 2(1): 212-17.

Meliasari, Dewi. (2019). "Pengetahuan Dan Dukungan Suami Berhubungan Dengan Tindakan Pemeriksaan Iva Pada Pasangan Usia Subur (Pus) Di Desa Sunggal Kanan Tahun 2014." Jurnal Ilmiah PANNMED (Pharmacist, Analyst, Nurse, Nutrition, Midwivery, Environment, Dentist) 9(3): 226-30.

Noviana, W. (2019). "Hubungan Dukungan Suami Dengan Perilaku Pemeriksaan Inspeksi Visual Asetat (IVA) Test Di Wilayah Kerja Puskesmas Cangkringan Sleman Yogyakarta." Jurnal Kesehatan Karya Husada Vol 7(7): 61-68.

Pelaihari, Puskesmas et al. (2020). “1, 2 , 3." 38.

Rahmawati, Nur Anisah, and Linda Dewanti. (2018). "Direct Experience with Cervical Cancer Patient, Husband Support, and Self-Perception as Determinant Factors of Women's Desire to Take VIA Screening Test." Kesmas 13(1): 36-42.
Sondang, Mei, and Ella Nurlaella Hadi. (2019). "Dukungan Suami Terhadap Perilaku WUS (30-50 Tahun) Dalam Melakukan Pemeriksaan IVA Di Wilayah Kerja Puskesmas Bondongan Tahun 2018." Gaster 17(2): 200.

Umami, Desi Aulia. (2019).

"Kuantitatif Non Eksperimental." Jm 7(12): 918.

Wahyuni, Puji, Christin Hiyana Tungga Dewi, and Ribkha Itha Idhayanti. (2019). "Determinat Factors Corellated with IVA Test Among Couple of Childbearing Age." Midwifery and Nursing Research 1(1): 38.

Wahyuni, Sri, and Ratna Puspita Adiyasa. (2018). "Hubungan Dukungan Suami Dengan Partisipasi Mengikuti Pemeriksaan Inspeksi Visual Asam Asetat (IVA) Pada Wanita Usia Subur Di Rw 04 Kelurahan Terban Gondokusuman Yogyakarta Tahun 2018 Kanker Serviks Merupakan Kanker Yang Menempati Nomor Urut Keempat Dari." 393: 129-41.

World Health Organization. (2020). "Elimination of Cervical Cancer: Thailand." International Agency for Research on Cancer (2019): 1-2. https://www.who.int/cancer/ countryprofiles/PAK_2020.pdf?ua=1. 